\title{
Europe's party-political centre of gravity, 1957-2003
}

Philip Manow, Armin Schäfer and Hendrik Zorn

\begin{abstract}
Europe's 'political space', its dimensionality and its impact on European policies have received increased academic attention lately. Yet, one very basic element of this political space, the party composition of EU member states' governments, has never been studied in a systematic way in the rich literature on European integration. In this paper we explain why the EU literature should pay more attention to the analysis of Europe's party-political 'centre of gravity'. We give a systematic overview of the party composition of member governments from 1957 to 2003. This includes analyses of how the support for integration, the left/right political conviction, and the ideological homogeneity or heterogeneity of the member states affected the Council over the course of time. We draw on expert surveys, the data of the Comparative Manifesto Project, and data about government composition.
\end{abstract}

KEY WORDS Centre of gravity; Council; integration theory; party politics.

\section{INTRODUCTION}

An abundance of anecdotal evidence highlights the importance of the partypolitical complexion of national governments for European integration. ${ }^{1}$ The literature emphasizes, for instance,

- the importance of Christian Democratic hegemony in the European Community's six founding states for early institution-building during the 1950s;

- the importance of the fact that the French-German 'integration motor' in the 1970s, 1980s, and 1990s always embodied a cross-party agreement between Social Democratic and conservative governments;

- or the importance of Europe's shift to the left in the second half of the 1990s for European Union (EU) policies, such as the employment title of the Amsterdam Treaty or the reinterpretation of the Stability and Growth Pact.

However, rich anecdotal evidence has not yet generated much academic activity in collecting systematic evidence on party-political government composition, 
which is a precondition if we want to theorize and systematically evaluate the role that party politics plays in the intergovernmental dynamics of European integration and in the inter-institutional politics between the Council, the Commission, and the European Parliament (EP). Still today we lack a systematic analysis of the party-political composition of EU member states' governments, how government composition has determined the party composition of the Council, and whether and how this has had an impact on EU politics and policies. We consider this to be a shortcoming.

With the increasing scholarly interest in Europe's political space, we think the time has come to - at least partially - 'replace names with variables' by going beyond an analysis that views national governments mainly as representatives of national (economic) interests. In our view, they should also be seen as the representatives of the political parties that form these governments. Analysing the party-political composition of EU member state governments is key if one wants to give answers to such important questions as: Has the party-political cohesion between the EU member states increased or decreased over time? Have periods of integration been periods of political homogeneity among the member countries' governments, whereas periods of stagnation of the European project corresponded with increased political heterogeneity? How have the several waves of EU enlargement affected political homogeneity within the Union? Has the Council's party-political position deviated systematically from that of the Parliament because of the 'second order effect' in European elections?

In this paper we offer an initial, systematic, longitudinal account of Europe's party-political centre of gravity along the two most important cleavage dimensions as identified in the literature: the left/right divide and the sovereignty/ integration cleavage (Hix 1999; Marks et al. 2002). This paper looks at national governments' position in political space and at the degree of party-political homogeneity in both the left/right and the sovereignty/integration dimensions. We show that the several waves of EU enlargement have made the Council more leftist and that the profound changes in the ideological orientation of left parties over the course of the 1980s and 1990s were more important for a liberal stance of the Council than the return of Social Democratic parties to national power in the second half of the 1990s.

The paper proceeds as follows: in section 2, we discuss in more detail why the analysis of the role of parties and of the national government composition in EU member states should have more prominence in EU studies. In section 3, we offer a quantitative analysis of the EU's centre of gravity from 1957 to today. ${ }^{2}$ In section 4 , we summarize our conclusions and give a brief outlook on future steps of analysis.

\section{PARTY-POLITICAL COMPOSITION OF EU MEMBER GOVERNMENTS AND THE DYNAMICS OF EUROPEAN INTEGRATION}

Previous EU studies developed no particularly strong interest in analysing in any greater detail the party-political government complexion in EU member states 
and its impact on European integration. (Neo-)realist and intergovernmentalist studies have asked why and to what extent member states have pooled sovereignty at the European level (Garrett 1993; Grieco 1995; Moravcsik 1994; Moravcsik 1998). In these accounts political actors labelled 'France', 'Germany', 'Britain', 'Italy', etc. occupy centre stage. They are understood to be either bearers of national interests or spokespersons of domestic economic coalitions. To what extent they are also party-political beasts has largely remained outside of systematic consideration. But governments that negotiate with each other over the course of European integration are composed of political parties. It is the very essence of democratic party competition that left and right parties differ over policies - if only to offer voters structured alternatives (Hinich and Munger 1992, 1997). Therefore, governments of different colouring can be expected to stand for and to pursue different policies also at the European level. For instance, it made a difference for the acceptance of the European Social Charter whether the Labour party or the Tories governed in Britain, and it was crucial for the success of the Constitutional Treaty whether the more pro-European socialist party (Partido Socialista Obrero Español) or the more integration-sceptic conservative Partido Popular would win the Spanish elections in the spring of 2004 . We believe that 'to take national preferences seriously' also means to take seriously the political positions of those parties that - as government parties - do not simply represent but interpret and shape what the national interest is.

Neo-functionalist analyses, in contrast, tended to focus on those EU actors like the European Commission and the European Court of Justice that almost by definition are on a non-partisan, non-national mission to fight for the European cause. According to these accounts, supranational actors have developed into 'engines of integration' whereas member governments are assigned rather reactive and defensive roles (Haas 1958; Stone Sweet et al. 2002). Neo-functionalists often argue that the Commission and the Court were able to push integration beyond the smallest common denominator preferred by the member states because they could exploit governments' 'heterogeneity of interest' (Burley and Mattli 1993: 54). But this interest heterogeneity was often of a party-political nature and - as we will show below - varied substantially over time. Again, it seems important to study more thoroughly whether and when EU member governments were politically aligned and whether agency drift of the Commission or the Court has been facilitated by partypolitical heterogeneity among member states.

A similar argument applies to those accounts that have studied European integration from a historical-institutionalist point of view. According to these accounts, member state governments have often delegated policy responsibilities to the European level in order to overcome credible commitment problems and to ensure effective implementation (Pierson 1996: 132). Yet, hedging against 'political uncertainty' (Moe 1990) by agreeing on EU-level regulation is a rational strategy only if member state policies vary with the party complexion of government. It is hard to see why governments should try to bind future 
governments to EU agreements if these successor governments - of whatever party-political complexion - will stand for exactly the same national position or will give voice to exactly the same privileged domestic interests in future intergovernmental negotiations. ${ }^{3}$ Similarly, why should problems of long-term credible commitment arise if member states' interests in the supranational arena remain largely unaffected by changes in government composition? ${ }^{4}$ Or put differently: why should a national government bind its successors to European policies even if these policies may not lie anymore in the national interest, given the assumption that the non-partisan 'national interest' is all that national governments care about?

EU studies informed by rational choice (RC) institutionalism have allowed for a wider range of actors who are considered to be decisive for European integration (Garrett et al. 1998; Tsebelis and Garrett 2001). In particular, these studies have acknowledged the increasingly important role that the EP has come to play in this process (Kreppel 2002). This has made this approach more sensitive for the party-political dimension of European integration. But it still seems to fall short of doing full justice to this dimension since RC institutionalists tend to buy into the rather apolitical picture of the member states and, correspondingly, of the Council painted by intergovernmentalism and neo-functionalism. Of course, it is not outright wrong that the Council represents the states, whereas the EP represents the citizens, but what tends to be ignored within such a perspective is that both states as well as citizens are represented via political parties. Yet this is of critical importance once we want to understand the inter-institutional politics between the Council and the Parliament in Europe's 'bicameral system' (Corbett et al. 2003; Tsebelis et al. 2001) that RC institutionalism is so right to highlight as being central for today's dynamic of the EU integration process. We know that the elections to the EP produce election outcomes that systematically diverge from those of national elections (Reif and Schmitt 1980; Reif 1984; Eijk et al. 1996). Studies also show an increasing importance for the left/right dimensions in Council and EP coalition formation (Mattila 2004; Hix et al. 2005). If these studies are right, we should expect that differences in the political location of the Council and the Parliament should have consequences for legislative politics in the EU. ${ }^{5}$ Of course, in order to address this question, we would first need systematic data on the party-political composition of EU member state governments. This is what this article provides.

Lately, academic interest in the salience and dimensions of Europe's political space has intensified considerably, and recent contributions have increasingly emphasized the importance of a 'horizontal' (i.e. left/right) dimension in addition to or crosscutting with the 'vertical' (i.e. sovereignty/integration) dimension that informed previous EU integration studies (Hix and Lord 1997; Hooghe et al. 2004). This has motivated research on party-political voting behaviour within the EP (Ladrech 1997; Kreppel and Tsebelis 1999; Kreppel and Hix 2003; Hix et al. 2005; Callaghan and Höpner 2005) and the Council (Mattila 2004; Zimmer et al. 2005), on national party competition 
over European issues (Marks and Wilson 2000; Gabel and Hix 2002; Pennings 2002), on the cleavage structure and 'issue congruence' of Europe's emerging 'political space' (Schmitt and Thomassen 1999; Selck 2004), on the feedback effects of European politics on national party systems (Mair 2001), or on the relations between national parliaments and EU-level politics (Martin 1995; Maurer and Wessels 2001). In these studies, party affiliation constantly turns out to be a significant predictor for the observable voting patterns in the Council and in the EP, often a better predictor than nationality or regional economic interests. This even seems to hold for Intergovernmental Conferences (Johansson 1999, 2002; Aspinwall 2002). These findings call for a more systematic inquiry into the party composition of EU member state governments and therefore also into the party-political centre of gravity of an EU institution like the Council, which often has been conceived to be 'purely intergovernmentalist' (Schmitt and Thomassen 1999: 6).

If recent studies indicate that party politics matters for EU politics, this reflects that parties do not merely passively represent a given national interest but actively shape it according to ideological positions and their domestic political agenda. A green party voted into national office with the promise to enact stricter environmental regulation is likely to also favour such an environmentalist course at the European level. A conservative party that campaigned nationally for a tougher stance on immigration will also fight for a more restrictive EU immigration policy. Liberal governments following a course of privatization and deregulation at home are very likely to back the same policies in the EU. In general, 'governments seek EU policies that are in line with their electoral commitments, accord with domestic public opinion, or directly benefit their voters and supporting interest groups' (Hix 2005: 409).

Electoral competition forces parties to offer voters distinct policy packages and to demonstrate reliability as well as responsibility (Downs 1957: 103-5). Since voters have limited information on policies, ideologies communicate a consistent set of propositions to the electorate (Hinich and Munger 1992, 1997). Once voted into office on different policy programmes, governing parties are committed to different interest groups and represent different social and economic interests. Mechanisms of democratic accountability subsequently push governments to deliver on their promises and to stick to their programmes. To deviate at the European level from national commitments would harm parties' credibility - and credibility is critically important in the democratic marketplace no matter whether parties are office-, policy-, or voteseeking, that is whether they value office intrinsically, whether they aim to influence policies, or whether they just seek to maximize their vote share (Strøm 1990). As long as the electorate is not completely cynical about politics, parties will have to care about their credibility and therefore will need to act as cohesively as possible at the national and the international levels.

It rarely makes substantial sense if a government supports supranational policies that contradict its domestic political agenda. On the contrary, national political parties predominantly conceive 'European policies as a means for realizing 
their visions of domestic society' (Marks and Wilson 1999: 131). Even if incidentally such a deviation may appear advantageous, governments will be highly reluctant to exploit these opportunities since voters would feel betrayed and are likely to punish instances of obvious policy hypocrisy. At the same time the national opposition has every incentive to alarm voters whenever a government applies double standards at the national and the supranational levels. Moreover, the democratic legitimacy of the European integration project still rests to a large extent upon the national electoral nexus (Lord 1998). Governments with an interest in integration therefore have reason to act coherently at the national and the European levels so as not to undermine Europe's precarious democratic legitimacy.

Hence, there are ample theoretical reasons to expect that parties pursue largely consistent policies in multi-level polities such as the EU. But then party-political government composition should be a good predictor for a member state's position on a given European issue or on European integration as such. In our explorative study, we report data on the political composition of $\mathrm{EU}$ member state governments and derive from this the party-political centre of gravity in the European Council. Given the previous arguments which suggested that parties have distinct ideological stances and that there are substantial differences in the various party-political visions for European integration, we will also report data on the positions of government parties aggregated for the conservative, Christian Democratic, liberal and Social Democratic party-families. We convey our findings about changes of attitudes toward European integration in the various national governments and look at the degree of partisan homogeneity within the EU. It is to these findings that we would now like to turn.

\section{EUROPE'S PARTY-POLITICAL CENTRE OF GRAVITY}

In this section we report on the party composition of EU member state governments, the Council's party-political centre of gravity, and the changes in governments' support for integration - as well as the differences between party-families in this regard. There are several methodological approaches that aim at locating a government's political position. Generally, we can distinguish between two major approaches: the first is to group the governing parties into party-families or on any kind of left/right scheme. The other is to generate so-called ideological centres of gravity (Gross and Sigelman 1984) that combine some power indicator (for coalition governments) with the respective party's position on an ideological scale. For this we need some measure of partisan preferences. Expert surveys can provide such information (Castles and Mair 1984; Huber and Inglehart 1995; Laver and Hunt 1992; Benoit and Laver 2006), but they have well-known problems of reliability and validity. Additionally, expert surveys typically reflect the situation at a given point in time. Even if we make the assumption that parties' preferences are stable over time, missing data for some parties remain a practical problem. 
The Comparative Manifesto Project (Budge et al. 2001) aimed at filling this gap. Using quantitative content analysis of party manifestos, the project promised to provide time-variant data on multidimensional preferences for most parties in 25 countries over much of the post-war period. Even with the huge effort, some of the project's basic assumptions might appear problematic: do party manifestos really mirror true preferences or are they merely rhetorical propositions in order to win elections? Despite some methodological and theoretical reservations, we will recur to the use of both kinds of data for two reasons: first, there simply is no empirical alternative. Second, even in the light of the aforementioned problems, the subsequent analyses should contain important information especially if we focus on trends and differences over time rather than on the comparison of absolute positions in policy space at given points in time.

More specific doubts may also be raised with respect to the centre-of-gravity approach in the EU context: if all major decisions in the EU require - either formally or informally - unanimity among the member states, what sense does it make to average the party-political positions of member governments? Would not an analysis of the position of the 'pivotal country' be more warranted? This, we claim, means taking the second step prior to the first. An analysis of the 'pivotal EU government' would first require placing countries on a left/right or issue-specific political spectrum. This is something that has not yet been undertaken systematically, and it is exactly what this paper does. Moreover, for any kind of outlier analysis we also need to know the 'sample mean'. In order to assess the distance between the 'most extreme' country and the EU mean on a given policy dimension, we need exactly the kind of centre-ofgravity approach that we apply here. As a first approximation to the question of political distances we report the standard deviation of our centre-of-gravity measure. We must leave it to future analyses to investigate with more detail the concrete location of EU member governments on given issue dimensions (of course, data quality would then become an even stronger constraint). Finally and more substantially, we also think that 'averaging' countries' partypolitical positions is justified since the EU literature shows that unanimity does not mean that each country possesses full veto power for each and every issue (Caporaso 1992; Héritier 1996) - preference outliers are disciplined by the majority and by norms of reciprocity. Even a Margaret Thatcher was unable to pursue a policy of 'the permanent no'.

For the subsequent analysis we use three sources in particular: one expert survey for parties' position on a left/right scale (Laver and Hunt 1992), one expert survey for parties' preferences towards European integration (Ray 1999), and the data of the Comparative Manifesto Project (Budge et al. 2001). In a first step we look at the government composition in European Community (EC)/EU member states since 1957 and group them into different party-families. Figure 1 reports the partisan 'colour' of the governments in the EC/EU member states. In order to distinguish party-families, we relied upon the party-family scheme of the Manifesto Project. Governments were 


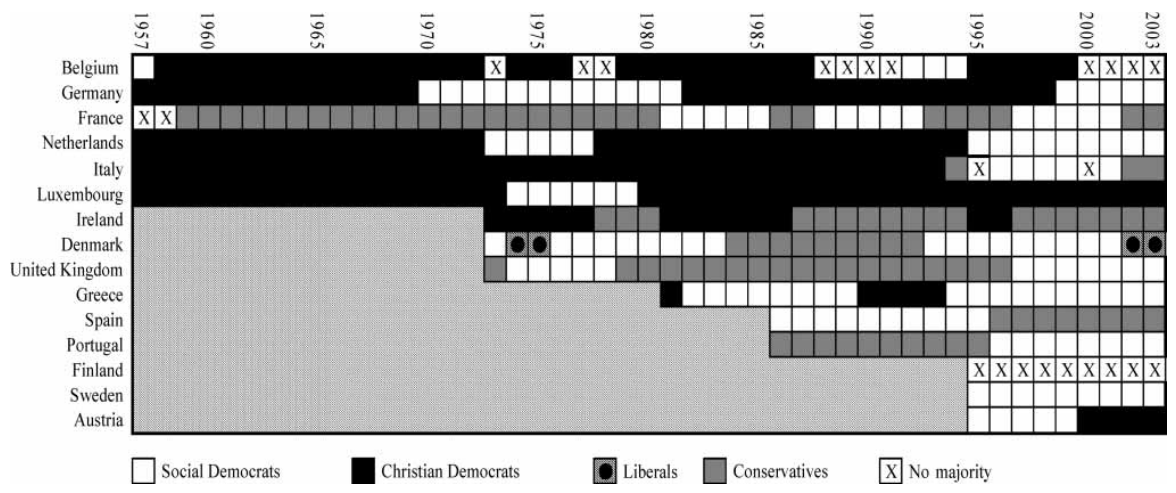

Figure 1 Partisan colour of the EC/EU member states

coded as 'Social Democrats', 'Christian Democrats', 'Liberals', or 'Conservatives'. For coalition governments we shaded the box according to the dominant party. We coded a government as dominated by one party-family if the respective parties held more than 50 per cent of the seats of all government-supporting members of parliament. For instance, the Rasmussen government that came to office in Denmark in January 1993 was made up of four coalition parties: the Socialdemokraterne, the Centrum-Demokraterne, the Kristeligt Folkeparti and the Venstre. The former two, classified as Social Democratic, held together 78 of the 83 parliamentary seats supporting the government. In two cases (the ÖVP-FPÖ coalition in Austria from 2000 and the second Dehaene government in Belgium 1995-99) there was a perfect 'draw', i.e. both parties/ party-families held exactly 50 per cent of the government supporting seats. In these cases the party affiliation of the prime minister tipped the scales. Furthermore, in years with government changes, we considered only the governments that were incumbent for at least six months.

In some cases, however, there was no dominance of a party-family. For instance, in the Martens government of 1988-89, the Social Democratic parties (PSB and BSP) held only 72 (or 48 per cent) of the 150 seats supporting the government (the Christian Democratic parties PSC and CVP held 62 and the VU held 16 seats). In these cases we indicated the absence of a clear majority.

In Figure 1, several developments immediately stand out. First, the strong Christian Democratic hegemony in the 1950s and 1960s; second, the fact that with each enlargement the EU shifted to the left; third, the strong role of conservative parties in the 1980s; and, fourth, the dominance of the left in EU member state governments in the second half of the 1990s.

In a more detailed analysis we may ask how changes in government composition have translated into changes in Europe's ideological centre of gravity. ${ }^{6}$ Here we take the Laver and Hunt (1992) data on the increase service vs. cut taxes' question as our basic left/right socioeconomic item. In a first step we compile the national centres of gravity by aggregating individual party positions 
in coalition governments. The resulting centre of gravity of a national government is the weighted sum of the individual parties' positions on the Laver/Hunt scale with a party's number of seats in parliament as the weight. Further, we calculated the daily weighted annual averages of the national centres of gravity if a government change occurred in a year. ${ }^{7}$ Finally, we compiled the simple average of the annual centres of gravity of all member countries in order to calculate the European centre of gravity. ${ }^{8}$

To extend the Laver and Hunt data back into the 1950s is not without problems. Yet we crosschecked the analysis with the data of the Comparative Manifesto Project and obtained almost identical results. Still, a cautious interpretation of the quantitative evidence is warranted, and attention should be focused on changes over time rather than on specific policy positions at any given point in time.

What kind of picture do the data produce? Figure 2 shows the development of the European centre of gravity over time: it reaches from 1 (extreme left) to 20 (extreme right). As can be seen in the chart, the European centre of gravity clearly mirrors the shift of national governments to the right in the late 1970s and early 1980s. The 1980s turned out to be quite a conservative decade, and only in the second half of the 1990s could Social Democratic parties fight their way back into government. The left interlude around the mid1970s was caused, to a considerable degree, by the first EU enlargement of membership to include Ireland, Denmark, and the UK in 1973. . $^{\text {Denmark }}$

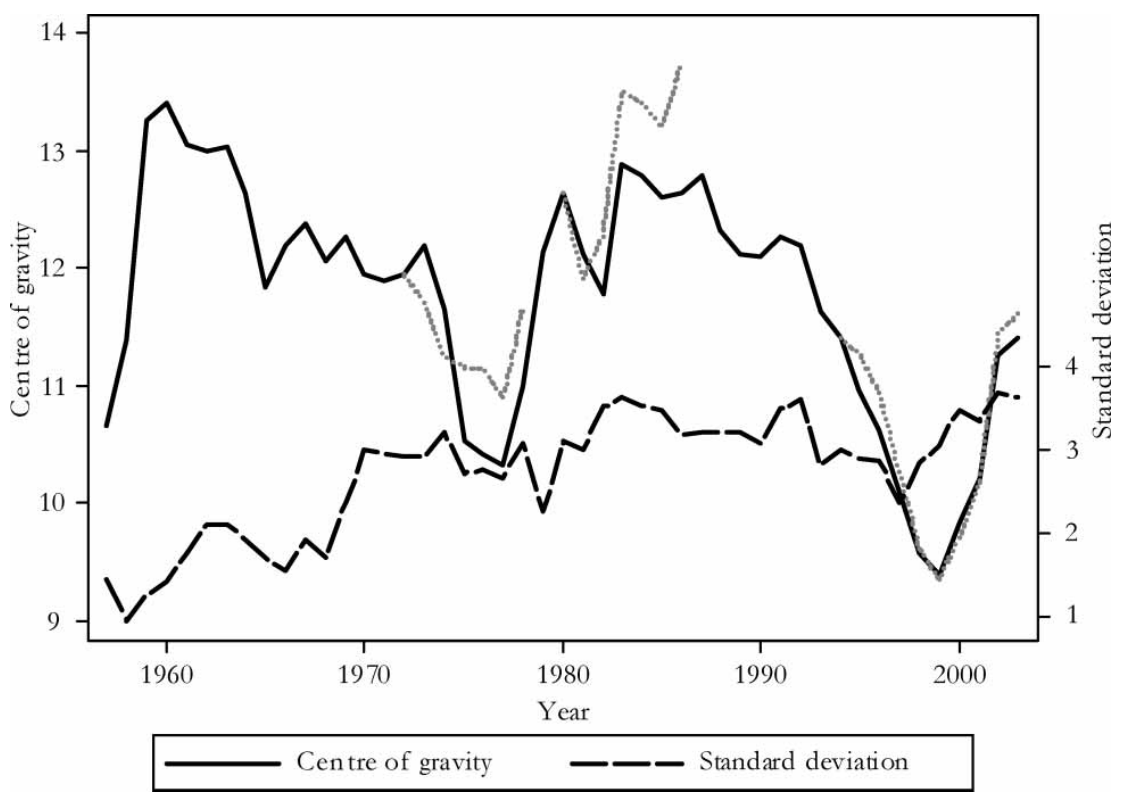

Figure 2 Ideological left/right stance of EU governments 
and the UK were being ruled by labour parties either at the point of entry into the Community or soon thereafter. Furthermore, Europe has steadily become politically more heterogeneous, as can be seen from the increasing standard deviation in Figure 2.

Following the same methodology, we can also calculate EU member state governments' 'support for integration' using the data generated by the survey of Leonard Ray (Figure 3). Again, the same caveats with respect to extending data back to the early years of European integration apply. Any interpretation of Figure 3 should consider changes only and should bear the limited data availability for the 1950s and 1960s in mind.

The averaged government positions are located on a 1 to 7 range from low salience and low support to high salience and high support. Interestingly, support for integration varies quite strongly in inverse relation to the 'leftness' of EU member state governments, with low points in both dimensions found in the second half of the 1970s and the 1990s - a finding further confirmed once we look at these dimensions from the party-family angle.

The box-plot in Figure 4 again contains the individual expert-coded values of support for integration (range 1-7, higher values suggesting stronger interest in integration issues, averaged over the available observations) taken from Ray (1999). The boxes display the median, the total range, the 25th percentile, and the 75th percentile. We included all parties that had at least once been part of the government on the respective national level since 1957 and

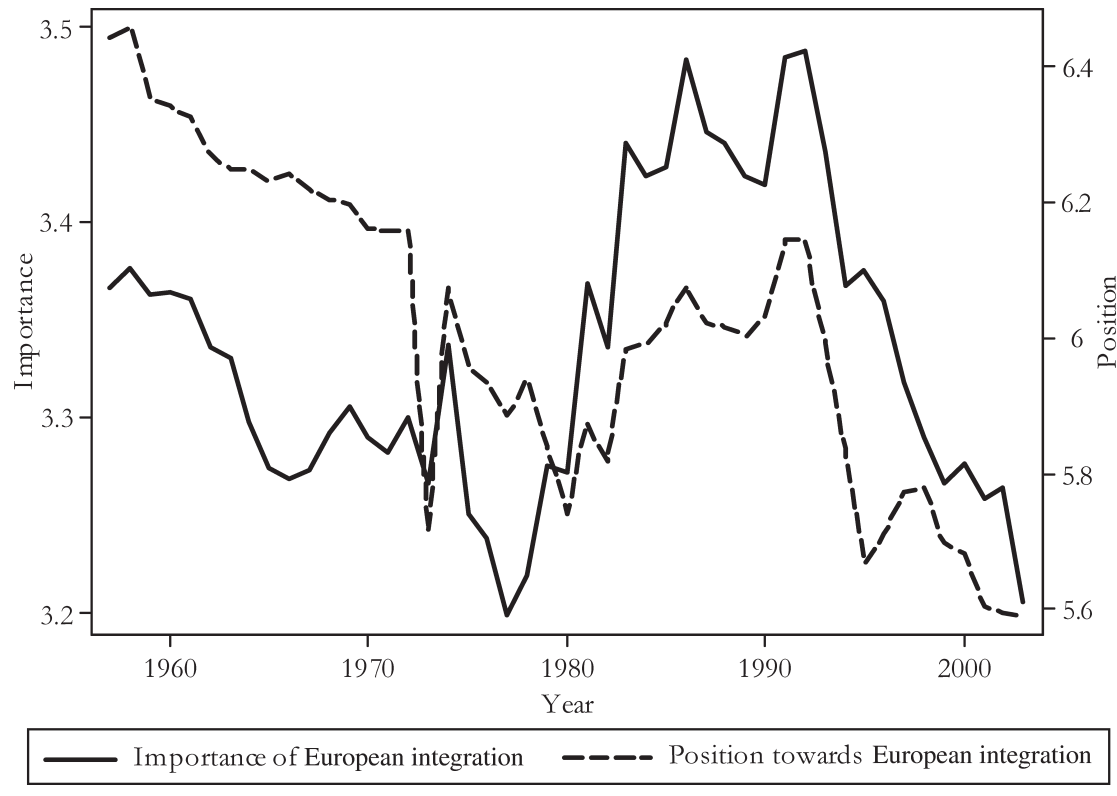

Figure 3 Support for integration of EU governments 


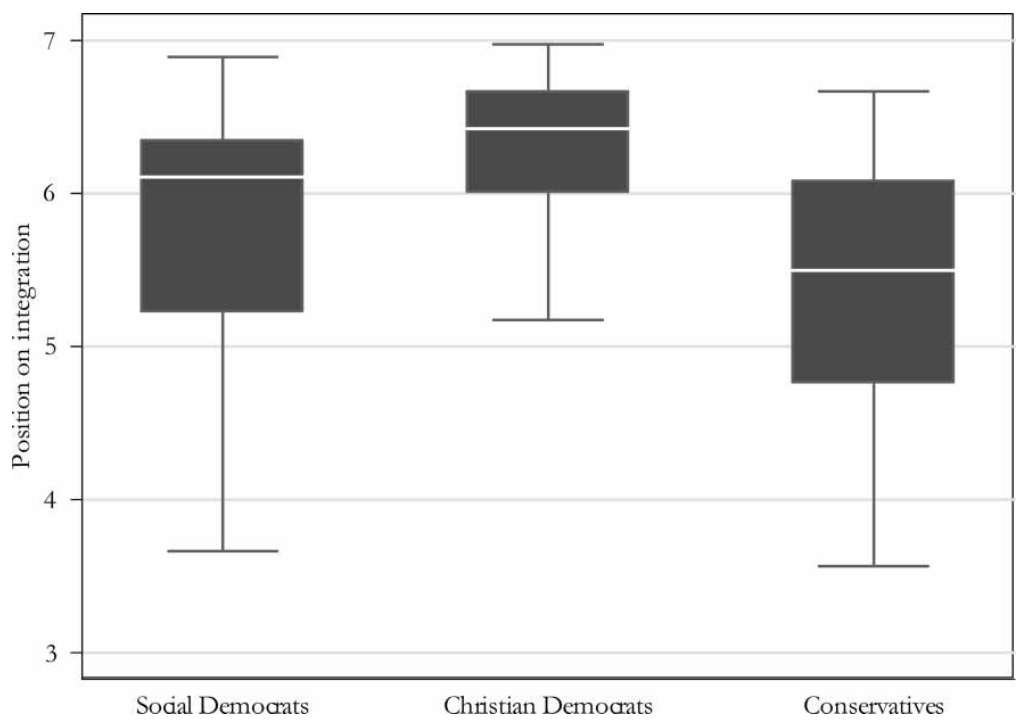

Figure 4 Support for integration according to party-family

grouped them according to the party-family scheme of the Manifesto Project. Figure 4 shows that the median values and the variance of the individual party positions differ a lot between the three analysed party-families. The Christian Democrats clearly show the highest median and the smallest bandwidth, while Social Democrats and conservatives are much less pronounced and display more internal heterogeneity.

Our data show variation in the centre of gravity and in governmental attitudes toward integration from the late 1950s to 2003 as well as differences between party-families in the pro-/contra EU dimension. National elections have not cancelled each other out at the European level but reflected common trends (cf. Manow and Döring 2008). In the past, electoral success for different party-families came in waves that coincided across EU member states. These have affected the party-political composition of the Council of the European Union. However, parties' positions on the left/right axis or their attitude towards European integration have also changed over time. Accordingly, we need to complement our analysis with additional data on some of these changes.

Differences between parties' positions can be detected in a more fine-grained perspective. In line with the view that 'ideologies' are signals to voters, partyfamilies differed markedly from each other in particular on issues that are relevant for the struggle between 'regulated' and 'liberal' capitalism in Europe (Hooghe and Marks 1999). But as the following figures show, these differences themselves remained not stable over time. ${ }^{10}$

Figure 5 uses the Comparative Manifesto Project Left/Right Index to detect preference shifts of the four party-families on the most general level. The most 


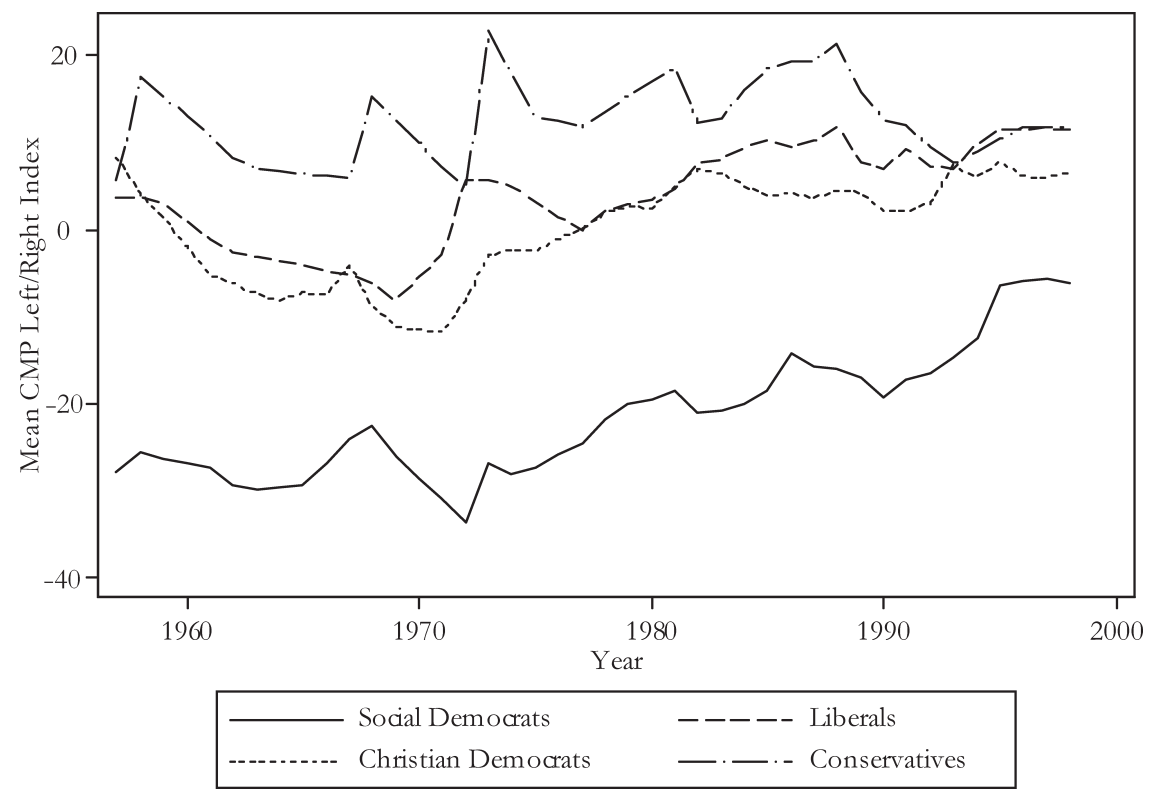

Figure 5 Preference moves of major party groups

striking finding is that both Christian and Social Democrats have continuously moved rightwards since the early 1970s. Despite remaining differences, we witness across party-families a conjoint ideological shift to the right. Hence, when Social Democracy for the first time held a majority in the Council at the end of the 1990s, the governing parties were far more centrist and far less interventionist than in the past. This might suggest a diminishing importance of differences in the party-political make-up of the Council in the future.

Figure 6 reinforces this point. It demonstrates that from 1970 onwards conservative parties developed an increasingly affirmative position toward free markets, which led to a near convergence with liberal parties. Christian Democrats followed in the early 1980s. The left, in contrast, remained reluctant until the 1990s. What is more, centre-right parties not only had converging ideological positions on economic policy but also valued European integration positively (see Figure 3). Not surprisingly, the relaunch of European integration between the mid-1980 and the early 1990s took place under the auspices of a Christian Democrat-liberal coalition - and was centred on economic integration (cf. Johansson 2002).

With regard to basic principles of economic governance, there are further signs of an ideological rapprochement between the main parties. Figure 7 maps the positions taken by party-families on market regulation. Again, the difference to the mid-1970s is striking. On this account, Social Democracy in 


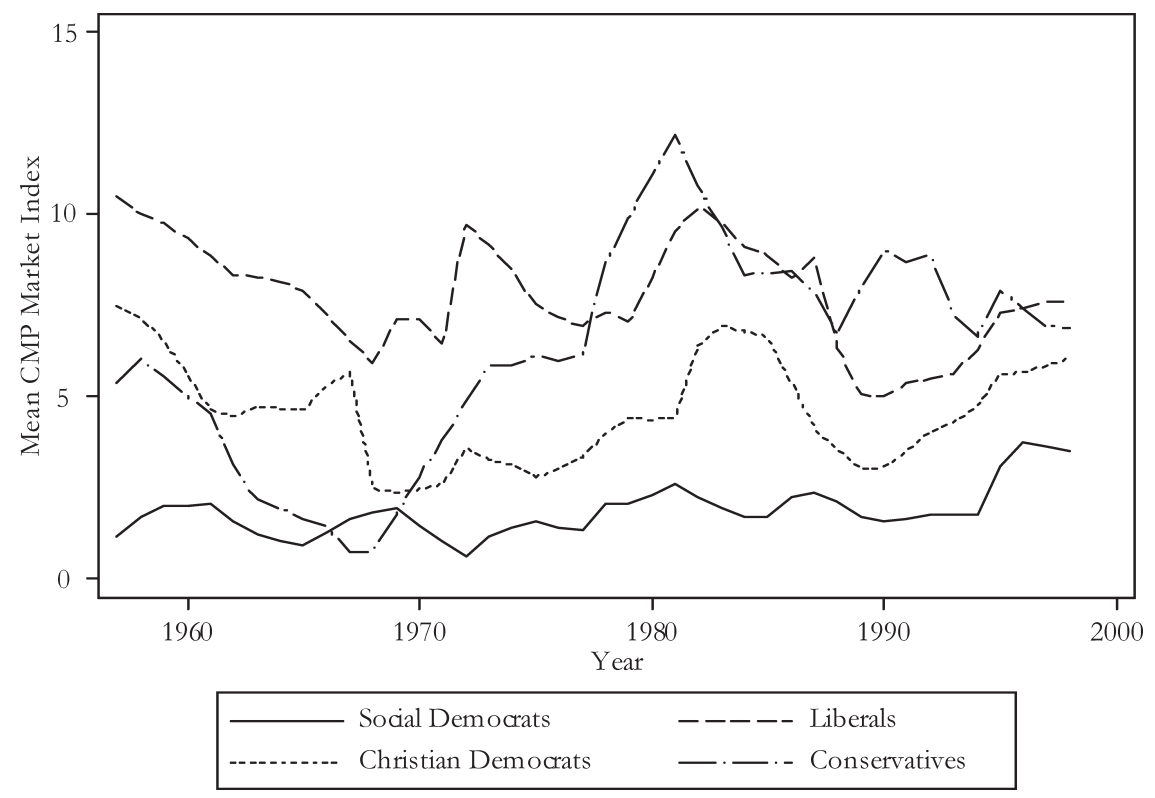

Figure 6 Affirmative positions on free markets

the late 1990s had more in common with its main competitors than with its own positions roughly three decades earlier.

In sum, this section has sought to demonstrate that governing parties in the EU have not only differed substantially in their support for European integration but also in how they value regulation of and social intervention in the market. Although we were able to show that the party-political composition of the Council has differed markedly over time, there were also some indicators pointing towards ideological convergence. Most importantly, centre-right and centre-left parties have become more alike in their economic outlook. Despite these observations, there are three reasons why we expect ideological difference between parties to remain important. First, even if differences on the left/right axis became less important, other cleavages might forcefully emerge at the national and the European level. For example, Hooghe et al. (2004) find that the positioning of parties on the libertarian/authoritarian axis proves decisive for a number of policy issues. Second, if party-political contestation over Europe increases at the national level, the Council may have to deal with a larger number of EU-sceptical members than in the past. Third, past enlargements increased the political heterogeneity among member states. Although it is beyond the scope of this article, all evidence suggests that Eastern enlargement has added substantially to the diversity of the Council. Growing heterogeneity could further complicate policy-making in the Council and render compromises more difficult. For all of these reasons a better knowledge of how national party 


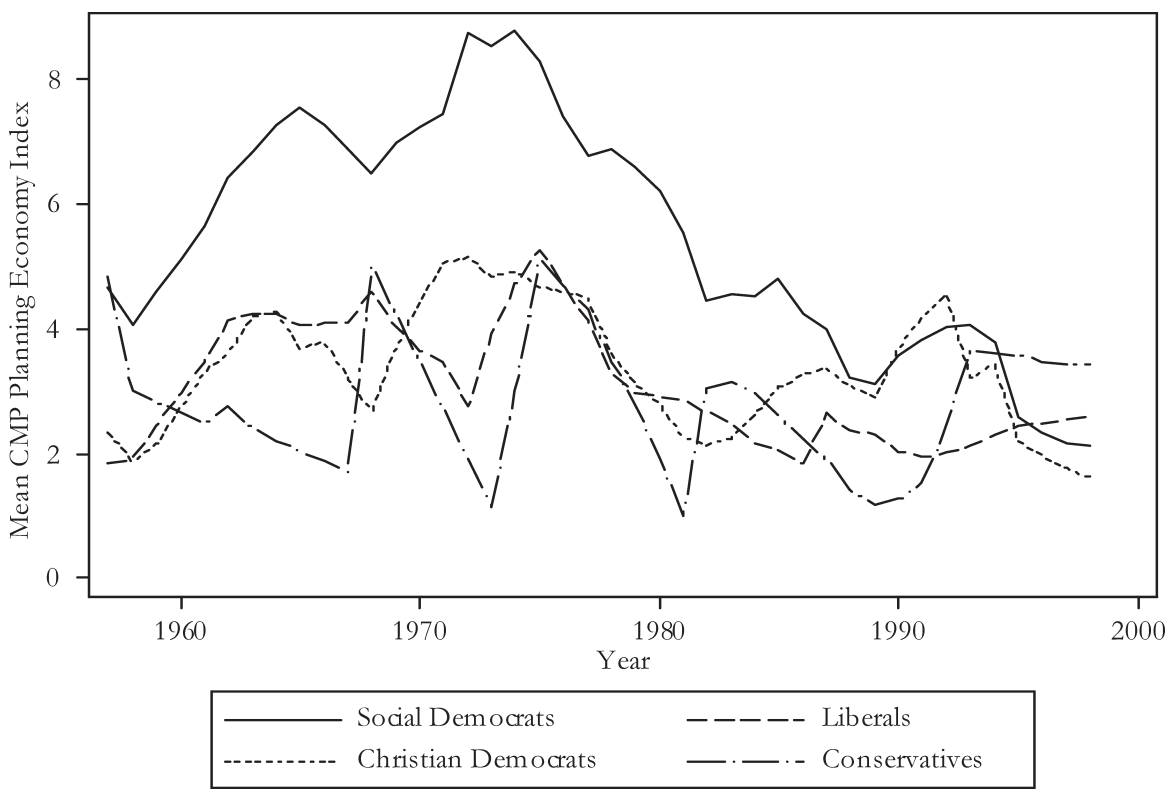

Figure 7 Affirmative positions on market regulation

politics translate into the composition of intergovernmental institutions will promote our understanding of EU politics.

\section{CONCLUSION}

In this article we have analysed Europe's party-political centre of gravity. More specifically, we have looked at the development of the left/right divide in the Council, the Council's support for integration, and the importance of European integration for EU member state governments of varying compositions.

In our view, existing theoretical approaches have only begun to acknowledge the importance of the party-political complexion of member state governments for European integration. As of yet, many contributions to the literature still see governments primarily as representatives of national interests. These national interests, in turn, are understood as reflecting a country's industrial structure or geo-political position, but not a government's political leanings. Alternatively, in neo-functionalist accounts governments are portrayed as rather passive and almost apolitical actors who reluctantly give in to the 'functionally required' supranational regulation of intensified transborder exchanges. Again, the exact party-political commitments of the governments in question seem to be of little relevance. Scholars have also highlighted countries' institutional egotism, which leads them to defend their national policy prerogatives against the persistent tendency of Court, Commission, and Parliament to assign Brussels more and more policy responsibilities - again largely irrespective of 
the substantive political consequences of transferring sovereignty to the EU in any given policy domain.

However, as we argued in this article, member state governments are composed of parties with distinct ideological profiles which they developed in order to offer to voters structured alternatives. Mechanisms of democratic accountability force parties to stick to their political programmes both at home and in international negotiations, even more so when the supranational arena increasingly decides the fate of governments' domestic programmes. Taking national preferences seriously would then also mean taking the preferences seriously of those parties that form national governments.

Clearly, this is intended to complement rather than to counter existing accounts of European integration. We concur with much of this literature's emphasis of governments as rational actors who strategically pursue national interests. Where we depart from existing approaches is in emphasizing how the electoral nexus profoundly shapes the domestic processes of preference formation in which the national interest is defined. According to our view, different coloured governments represent different social and economic interests. National elections determine government composition and thereby also determine which of the competing economic and social interest coalitions will enjoy privileged access and political representation.

Obviously, the importance of party politics differs across policy fields. We do not suggest that political ideology always dominates national processes of interest intermediation, but that it always, albeit to varying degrees, influences these processes. Clearly, conflicts over the common agricultural policy, fishing quotas or structural funds primarily involve 'who gets what' rather than controversies marked by profound ideological differences. Moreover, often political ideologies and material interests mix. For example, the interests of the Spanish agricultural sector in more immigration and that of the German construction worker unions in less immigration into the EU are likely to lead to differing positions of the Spanish and the German governments, even if both happen to be led by Social Democratic parties. In order to assess the relative importance of the 'partisan dimension' of European integration, we need a systematic analysis of the party-political government composition in EU member states. This is what we have offered in this article. Against the background of this analysis future studies may address such questions as: in which policy sectors does a partisan account of European integration work best? Where are traditional realist or intergovernmentalist assumptions about member state preferences appropriate? It is also in this sense that we understand our contribution to be complementary to the existing studies in the field.

In future steps of analysis we may also want to ask how shifts of the centre of gravity have affected legislative output in Europe. Of particular interest is the issue of how the EP and the Council interact. Do diverging majorities between the Council and the Parliament lead to more frequent blockages of Commission proposals (Manow and Döring 2008)? Does the chance that EP amendments will be successful increase with increasing party-political 
heterogeneity in the Council? These are crucial questions for follow-up studies on the importance of the party-political make-up of governments for supranational negotiations and institution-building.

Biographical notes: Philip Manow is Professor of Political Science and Public Administration at the University of Konstanz, Germany. Armin Schäfer is Researcher at the Max Planck Institute for the Study of Societies, Cologne, Germany. Hendrik Zorn is a Ph.D. student at the Max Planck Institute for the Study of Societies, Cologne, Germany.

Addresses for correspondence: Philip Manow, Universität Konstanz, Fachbereich für Politik- und Verwaltungswissenschaft, Room D 241, Universitätsstr. 10, 78464 Konstanz, Germany Tel: +49 (0)7531 88-3617. email: philip.manow@ uni-konstanz.de/Armin Schäfer, Max Planck Institute for the Study of Societies, Paulstr. 3, 50676 Köln, Germany. Tel: + 49 (0)221 2767164. email: as@mpifg.de/Hendrik Zorn, Max Planck Institute for the Study of Societies, Paulstr. 3, 50676 Köln, Germany. Tel: +49 (0)221 2767184. email: zh@mpifg.de

\section{NOTES}

1 We would like to thank Christian Joerges, Stephan Leibfried, Susanne K. Schmidt, Ulrich Sedelmeier, Oliver Treib, and two anonymous reviewers for very valuable comments.

2 The centre-of-gravity approach was first used to analyse national parliaments; see Gross and Sigelman (1984). Section 3 below deals with its technical details.

3 Hix and Lord (1997: 4) have argued that in European politics 'key players may rush to form agreements while there is a favourable conjuncture in the domestic politics of member states' to lock 'successor governments into EU-level agreements.' Yet, a 'favourable conjuncture' must be defined also, if not foremost, in terms of partisan homogeneity among the EU member states. Again, we would need systematically compiled information on the party-composition of $\mathrm{EU}$ member states in order to recognize a 'favourable conjuncture' when we see one. Such information seems even more warranted today since the regular Heads of State/European Council meetings have substantially increased in importance for the fate of the European integration process since the 1990s.

4 Pierson (1996: 140) has emphasized the importance of 'changes in preferences' of EU member states, so that at any given point in time the EU is never simply the sum of the 'interest parts' of all member countries. For Pierson, the most important source of preference change is 'change in government'. We agree. We would then like to know when and how voters in EU member states changed preferences.

5 Tsebelis has argued that the EP, under the co-operation procedure, can become a conditional agenda-setter in the case where heterogeneous interests prevail within the Council (Tsebelis 1994; Tsebelis and Kreppel 1998). One important source of 'interest heterogeneity' within the Council is undeniably the diversity of its political composition. Therefore, we would like to know something about the partypolitical heterogeneity in the Council. 
6 We do not weight national centres of gravity with the different national voting weights in the Council, assuming that unanimity was the predominant voting rule for most Council decisions in most of the period covered. A more detailed analysis must be left to future publications.

7 Take, for instance, a party coalition in country c with $n$ parties: if $\mathrm{X}_{\mathrm{i}}$ denotes the number of seats of party $\mathrm{i}$ in parliament and $\mathrm{LH}_{\mathrm{i}}$ its position on the Laver/Hunt scale, then the centre of gravity $(\mathrm{CoG})$ of a single government $(\mathrm{k})$ is compiled as $\mathrm{CoG}_{\mathrm{k}}=\sum_{\mathrm{i}=1}^{\mathrm{n}}\left(\mathrm{x}_{\mathrm{i}} / \sum_{\mathrm{j}=1}^{\mathrm{n}} \mathrm{x}_{\mathrm{j}}\right) \mathrm{LH}_{\mathrm{i}}$. In years with government changes we calculated the annual means of the individual $\mathrm{CoGs}\left(\mathrm{CoG}_{\mathrm{k}}\right)$, weighted by the days of incumbency $(\mathrm{d}): \overline{\mathrm{CoG}}=\sum_{\mathrm{k}=1}^{\mathrm{n}}\left(\mathrm{d}_{\mathrm{k}} / 365\right) \mathrm{CoG}_{\mathrm{k}}$.

8 Take Germany in 1998 as an example: there were two coalition governments with two parties respectively. In the first part of the year the CDU/CSU (L/H Index: 13,4) had 294 seats in parliament. Its coalition partner, the FDP (Index: 15,7), held 47 seats. A CoG of 13,69 results. In contrast, the subsequent coalition of the SPD with the Greens had a CoG of 6,35. The CoG value for Germany in 1998 is now calculated as the sum of the individual government CoGs, weighted by the days of incumbency. Thus a value of $269 / 365^{*} 13,7+95 / 365^{*} 6,4=11,5$ results. We repeated this procedure for all member countries. The European CoG for 1998 is then the arithmetic mean of all 15 EU member countries $(9,6)$.

9 Three additional lines help in parsing the impact of the community extensions in 1973, 1981-86, and 1995. The dotted lines show the respective mean values, had the respective enlargements not taken place.

10 For the analysis of preference shifts in Figures 5 and 6, we transformed the Comparative Manifesto Project dataset (Budge et al. 2001) on a yearly base. We used the indexes of the parties' positions on the left/right political spectrum and on 'planned economy', 'market economy', and 'welfare' issues. The party values for the years between elections have been linearly interpolated (i.e. we assumed that the positions changed constantly between the elections following a linear trend). We then grouped the parties in the dataset using the integrated party-family coding scheme. We again classified the groups as 'Left', 'Christian Democrat', 'Liberal', and 'Right' and omitted regionalist and special-interest parties. For the calculation of country-specific values, we weighted the annual scores by the relative share of seats in parliament. We then generated the arithmetic mean.

\section{REFERENCES}

Aspinwall, M. (2002) 'Preferring Europe. Ideology and national preferences on European integration', European Union Politics 3(1): 81-111.

Benoit, K. and Laver, M. (2006) Party Policy in Modern Democracies, London: Routledge.

Budge, I. et al. (2001) Mapping Policy Preferences: Estimates for Parties, Electors, and Governments 1945-1998, Oxford: Oxford University Press.

Burley, A.-M. and Mattli, W. (1993) 'Europe before the Court: a political theory of legal integration', International Organization 47(1): 41-76.

Callaghan, H. and Höpner, M. (2005) 'European integration and the clash of capitalisms: political cleavages over takeover liberalization', Comparative European Politics 3(3): 307-32.

Caporaso, J.A. (1992) 'International relations theory and multilateralism: the search for foundations', International Organization 46: 599-632.

Castles, F.G. and Mair, P. (1984) 'Left-right political scales: some "expert” judgments', European Journal of Political Research 12: 73-88. 
Corbett, R., Jacobs, J. and Shackleton, M. (2003) The European Parliament, Vol. 5, London: John Harper.

Downs, A. (1957) An Economic Theory of Democracy, New York: Harper.

Eijk, C.v.d., Franklin, M. and Marsh, M. (1996) 'What voters teach us about Europewide elections: what Europe-wide elections teach us about voters', Electoral Studies 15(2): 149-66.

Gabel, M. and Hix, S. (2002) 'Defining the EU political space - an empirical study of the European elections manifestos, 1979-1999', Comparative Political Studies 35(8): 934-64.

Garrett, G. (1993) 'The politics of Maastricht', Economics and Politics 5(2): 105-25.

Garrett, G., Kelemen, R.D. and Schulz, H. (1998) 'The European Court of Justice, national governments, and legal integration in the European Union', International Organization 52(1): 149-76.

Grieco, J.M. (1995) 'The Maastricht Treaty, economic and monetary union and the neo-realist research programme', Review of International Studies 21(1): $21-40$.

Gross, D.A. and Sigelman, L. (1984) 'Comparing party systems: a multidimensional approach', Comparative Politics 16(4): 463-79.

Haas, E.B. (1958) The Uniting of Europe: Political, Social, and Economic Forces 1950-1957, Stanford: Stanford University Press.

Héritier, A. (1996) 'The accommodation of diversity in European policy-making and its outcome: regulatory policy as a patchwork', Journal of European Public Policy 3(2): $149-67$.

Hinich, M.J. and Munger, M.C. (1992) 'A spatial theory of ideology', Journal of Theoretical Politics 4(1): 5-30.

Hinich, M.J. and Munger, M.C. (1997) Analytical Politics, Cambridge: Cambridge University Press.

Hix, S. (1999) 'Dimensions and alignments in European Union politics: cognitive constraints and partisan responses', European Journal of Political Research 35(1): 69106.

Hix, S. (2005) The Political System of the European Union, 2nd edn, Basingstoke: Palgrave Macmillan.

Hix, S. and Lord, C. (1997) Political Parties in the European Union, Basingstoke: Macmillan Press.

Hix, S., Noury, A.G. and Roland, G. (2005) 'Power to the parties: cohesion and competition in the European Parliament, 1979-2001', British Journal of Political Science 35(2): 209-34.

Hooghe, L. and Marks, G. (1999) 'The struggle over European integration', in H. Kitschelt et al. (eds), Continuity and Change in Contemporary Capitalism, Cambridge: Cambridge University Press, pp. 70-97.

Hooghe, L., Marks, G. and Wilson, C.J. (2004) 'Does left/right structure party positions on European integration?', in G. Marks and M.R. Steenbergen (eds), European Integration and Political Conflict, Cambridge: Cambridge University Press, pp. $120-40$.

Huber, J. and Inglehart, R. (1995) 'Expert interpretations of party space and party locations in 42 societies', Party Politics 1(1): 73-111.

Johansson, K.M. (1999) 'Tracing the employment title in the Amsterdam Treaty: uncovering transnational coalitions', Journal of European Public Policy 6(1): $85-101$.

Johansson, K.M. (2002) 'Another road to Maastricht. The Christian Democrat coalition and the quest for European union', Journal of Common Market Studies 40(3): 871-93.

Kreppel, A. (2002) The European Parliament and Supranational Party System: A Study in Institutional Development, Cambridge: Cambridge University Press. 
Kreppel, A. and Hix, S. (2003) 'From "grand coalition" to left-right confrontation: explaining the shifting structure of party competition in the European Parliament', Comparative Political Studies 36(1/2): 75-96.

Kreppel, A. and Tsebelis, G. (1999) 'Coalition formation in the European Parliament', Comparative Political Studies 32(8): 933-66.

Ladrech, R. (1997) 'Partisanship and party formation in European Union politics', Comparative Politics 29(2): 167-85.

Laver, M. and Hunt, W.B. (1992) Policy and Party Competition, London: Routledge.

Lord, C. (1998) Democracy in the European Union, Sheffield: Sheffield Academic Press.

Mair, P. (2001) 'The limited impact of Europe on national party systems', in K.H. Goetz and S. Hix (eds), Europeanised Politics? European Integration and National Political Systems, London: Frank Cass, pp. 27-51.

Manow, P. and Döring, H. (2008) 'Electoral and mechanical causes of divided government in the European Union', Comparative Political Studies (forthcoming).

Marks, G. and Wilson, C. (1999) 'National parties and the contestation of Europe', in T. Banchoff and M.P. Smith (eds), Legitimacy and the European Union. The Contested Polity, London/New York: Routledge, pp. 113-33.

Marks, G. and Wilson, C.J. (2000) 'The past in the present: a cleavage theory of party response to European integration', British Journal of Political Science 30: 433-59.

Marks, G., Wilson, C.J. and Ray, L. (2002) 'National political parties and European integration', American Journal of Political Science 46(3): 585-94.

Martin, L.L. (1995) 'The influence of national parliaments on European integration', in B. Eichengreen, J. von Hagen and J. Frieden (eds), Politics and Institutions in an Integrated Europe, Berlin/New York: Springer, pp. 65-92.

Mattila, M. (2004) 'Contested decisions: empirical analysis of voting in the European Council of Ministers', European Journal of Political Research 43(1): 29-50.

Maurer, A. and Wessels, W. (2001) National Parliaments on Their Way to Europe: Losers or Latecomers?, Baden-Baden: Nomos.

Moe, T.M. (1990) 'Political institutions: the neglected side of the story', Journal of Law, Economics, \& Organization 6: 213-53.

Moravcsik, A. (1994) 'Preferences and power in the European Community: a liberal intergovernmentalist approach', in S. Bulmer and A. Scott (eds), Economic and Political Integration in Europe: Internal Dynamics and Global Context, Oxford: Blackwell Publishers, pp. 29-80.

Moravcsik, A. (1998) The Choice for Europe. Social Purpose and State Power from Messina to Maastricht, London: UCL Press.

Pennings, P. (2002) 'The dimensionality of the EU political space: the European elections 1999', European Union Politics 3(1): 123-63.

Pierson, P. (1996) "The path to European integration: a historical institutionalist analysis', Comparative Political Studies 29(2): 123-63.

Ray, L. (1999) 'Measuring party orientation towards European integration: results from an expert survey', European Journal of Political Research 36: 283-306.

Reif, K. (1984) 'National electoral cycles and European elections 1979 and 1984', Electoral Studies 3(3): 244-55.

Reif, K. and Schmitt, H. (1980) 'Nine second-order national elections: a conceptual framework for the analysis of European election results', European Journal of Political Research 8(1): 3-45.

Schmitt, H. and Thomassen, J. (eds) (1999): Political Representation and Legitimacy in the European Union, Oxford: Oxford University Press.

Selck, T.J. (2004) 'On the dimensionality of European Union legislative decisionmaking', Journal of Theoretical Politics 16(2): 203-22. 
Stone Sweet, A., Sandholtz, W. and Fligstein, N. (eds) (2002): The Institutionalization of Europe, Oxford: Oxford University Press.

Strøm, K. (1990) 'A behavioral theory of competitive political parties', American Journal of Political Science 34(2): 565-98.

Tsebelis, G. (1994) 'The power of the European Parliament as a conditional agenda setter', American Political Science Review 88(1): 128-41.

Tsebelis, G. and Garrett, G. (2001) 'The institutional foundations of intergovernmentalism and supranationalism in the European Union', International Organization 55(2): 357-90.

Tsebelis, G. and Kreppel, A. (1998) 'The history of conditional agenda-setting in European institutions', European Journal of Political Research 33(1): 41-71.

Tsebelis, G. et al. (2001) 'Legislative procedures in the European Union: an empirical analysis', British Journal of Political Science 31(4): 573-99.

Zimmer, C., Schneider, G. and Dobbins, M. (2005) 'The contested Council: conflict dimensions of an intergovernmental EU institution', Political Studies 53(2): 403-22. 